\title{
Unusual immunophenotype displayed by histiocytes in haemophagocytic lymphohistiocystosis
}

\author{
T HERLIN, * G PALLESEN, $\dagger$ T KRISTENSEN, $\ddagger$ N CLAUSEN*
}

From the Departments of * Pediatrics, $†$ Laboratory of Immunohistology, University Institute of Pathology, and $\ddagger$ Tissue Typing Laboratory, University Hospital, Aarhus, Denmark

SUMMARY Extensive immunophenotypic studies in a $2 \frac{1}{2}$ month old girl with haemophagocytic lymphohistiocytosis were performed to characterise the proliferating histiocytes of the disease. The cells strongly expressed conventional macrophage antigens, but unexpectedly, there was a dissociated expression of the CDla antigen (reacting with the monoclonal antibody NA1/34 but not with OKT6) and intracellular S-100 protein by the haemophagocytic lymphohistiocytosis histiocytes. These findings indicate that there is a "hybrid" phenotype between the two main arms of the mononuclear phagocyte system-namely, Langerhans' cells and phagocytic macrophages.

Haemophagocytic lymphohistiocytosis (HL) is a rare, usually familial, and fatal disease of early childhood. ${ }^{1-5}$ The onset of symptoms occurs before 3 months of age in about two thirds of patients. Clinical features include recurrent fever, hepatosplenomegaly, anorexia, pallor, and cerebral irritability, but the clinical and pathological variability of this disease often results in a delayed or post mortem diagnosis. In most cases the disease is inherited as an autosomal recessive trait, ${ }^{14}$ but $25 \%$ of cases have no known family history. ${ }^{45}$ The pathognomonic cell in the tissue infiltrates has a morphological resemblance to cells of the mononuclear phagocyte system. Defects in both humoral and cellular immunity have been described by a few investigators. ${ }^{67}$

We report a patient in whom a functional primary B lymphocyte defect was detected before dissemination of HL. In an attempt to characterise the infiltrating cell of $\mathrm{HL}$ and the underlying immune deficiency in more detail we performed immunohistological investigations on tissue samples of several organs frozen at necropsy using a wide panel of monoclonal antibodies.

\section{Case report}

A $21 / 2$ month old girl of previously normal health and growth was admitted with a severe acute illness, characterised by high fever, dehydration, and hepatomegaly. There was no clinically important family history. Laboratory investigations showed anaemia (haemoglobin $5.6 \mathrm{mmol} / \mathrm{l}$ ), hypoproteinaemia, raised SGOT, thrombocytopenia (platelets $40 \times 10^{9} / 1$ ), and hypertriglyceridaemia (serum triglycerides 3.7

Accepted for publication 25 June 1987 $\mathrm{mmol} / \mathrm{l}$, normal range $0.5-2.0 \mathrm{mmol} / \mathrm{l}$ ). The bone marrow was hyperplastic with normally differentiated cells. A normal leucocyte count with relative lymphocytosis was repeatedly observed. The child clinically returned to normal within three weeks with conservative treatment, and the liver size decreased. Several relapses with high fever, diarrhoea, and hepatomegaly occurred at three to four week intervals. Final deterioration with generalised oedema, hepatic insufficiency, a profuse haemorrhagic diathesis and seizures then developed and she died at the age of 10 months.

\section{IMMUNOLOGICAL STUDIES}

Serum IgA concentrations were low throughout the illness $(0.03$ to below $0.01 \mathrm{~g} / \mathrm{l}$, normal range $0.08-0.98$ $\mathrm{g} / \mathrm{l})$. Serum $\mathrm{IgG}$ fell from normal $(3.0 \mathrm{~g} / \mathrm{l})$ at the age of 4 months to below $0 \cdot 1 \mathrm{~g} / \mathrm{l}$ at 6 months of age (normal range $2.06-11.25 \mathrm{~g} / \mathrm{l})$. The concentrations of IgM were within the normal range $(0.28-0.71 \mathrm{~g} / \mathrm{l})$ and serum IgD and IgE were not increased. At 6 months of age immunological investigations were performed during a quiescent period. Natural killer cell activity was in the low to normal range, but, unlike control leucocytes, enhanced killer cell activity after incubation with interferon was not observed. Lymphocyte antibody dependent, cell mediated cytotoxicity was depressed. The distribution of $\mathrm{T}$ and $\mathrm{B}$ lymphocytes in the peripheral blood was normal, the CD4:CD8 ratio being 2.6 . Lymphocyte responses to mitogen and antigen stimulation were normal. B lymphocyte function, evaluated by an indirect plaque forming cell assay, ${ }^{8}$ showed no in vitro immunoglobulin $G, A$, or $M$ synthesis, either in presence of the patient's own T cells or with control T cells, indicating functional B lymphocyte defect. On the other hand, the patient's T 
cells, added to control B cells, completely suppressed immunoglobulin synthesis. This further indicated a high functional $\mathrm{T}$ suppressor cell associated activity.

\section{Pathology}

Necropsy was performed 18 hours after death. It showed jaundice, hepatosplenomegaly and cerebral oedema, but no lymph node enlargement. Microscopy showed a diffuse infiltration of lymphocytic and histiocytic cells in the organs. The infiltrates were particularly prominent in the spleen, liver, kidney, lymph nodes, bone marrow and central nervous system. In the brain the infiltrate was perivascular and

Table Immunophenotype of proliferating histiocyte in a case of haemophagocytic lymphohistiocytosis

\begin{tabular}{|c|c|c|c|c|c|c|}
\hline $\begin{array}{l}\text { Antigen defined } \\
\text { by antibody }\end{array}$ & Antibody & Source & $\begin{array}{l}\text { Haemophagcytic } \\
\text { lymphohistiocytosis }\end{array}$ & $\begin{array}{l}\text { Phagocytic } \\
\text { histiocytes }\end{array}$ & Langerhans' cells & \\
\hline $\begin{array}{l}\text { B Cell antigens } \\
\text { CD9 } \\
\text { CD10 } \\
\text { CD19 } \\
\text { CD20 } \\
\text { CD21 } \\
\text { CD22 } \\
\text { CD23 } \\
\text { CD24 } \\
\text { CD37 } \\
\text { CD38 } \\
\text { CD39 } \\
\text { CDw40 }\end{array}$ & $\begin{array}{l}\text { J2 } \\
\text { F } 103.12 \\
\text { B4 } \\
\text { B1 } \\
\text { HB5 } \\
\text { To15 } \\
\text { MHM6 } \\
\text { BA1 } \\
\text { G28-1 } \\
\text { OKT10 } \\
\text { G28-10 } \\
\text { G28-5 }\end{array}$ & $\begin{array}{l}\text { WS* } \\
\text { Own laboratory } \\
\text { WS } \\
\text { WS } \\
\text { WS } \\
\text { WS } \\
\text { WS } \\
\text { WS } \\
\text { WS } \\
\text { Ortho Diagnostic } \\
\text { wS } \\
\text { WS }\end{array}$ & $\begin{array}{l}2+ \\
0 \\
3+ \\
3+ \\
3+ \\
0 \\
0 \\
2+ \\
2+ \\
2+ \\
2+ \\
3+\end{array}$ & $\begin{array}{l}3+ \\
2+ \\
1+ \\
1+ \\
2+ \\
0 \\
0 \\
2+ \\
1+ \\
0 \\
3+ \\
3+\end{array}$ & $\begin{array}{l}\text { Not assessed } \\
0 \\
0 \\
0 \\
0 \\
0 \\
0 \\
\text { Not assessed } \\
1+ \\
3+ \\
1+ \\
1+\end{array}$ & \\
\hline $\begin{array}{l}\text { T cell antigens } \\
\text { CDla } \\
\text { CDla } \\
\text { CD1b } \\
\text { CD2 } \\
\text { CD3 } \\
\text { CD4 } \\
\text { CD5 } \\
\text { CD6 } \\
\text { CD7 } \\
\text { CD8 } \\
\text { CD27 } \\
\text { CD28 } \\
\text { CDw29 } \\
\text { p180 }\end{array}$ & $\begin{array}{l}\text { OKT6 } \\
\text { NA1/34 } \\
\text { NU-T2 } \\
\text { DAKO-T11 } \\
\text { UCHT1 } \\
\text { Anti-Leu-3a } \\
\text { Tu71 } \\
\text { Tu33 } \\
\text { Tu14 } \\
\text { DAKO-T8 } \\
\text { OKT18A } \\
\text { Kolt-2 } \\
\text { 4B4 } \\
\text { UCHL1 }\end{array}$ & $\begin{array}{l}\text { Ortho Diagnostic } \\
\text { Dakopatts } \\
\text { Nichirei Corporation } \\
\text { Dakopatts } \\
\text { P Beverley } \\
\text { Becton Dickinson } \\
\text { A Ziegler } \\
\text { A Ziegler } \\
\text { A Ziegler } \\
\text { Dakopatts } \\
\text { WS } \\
\text { Nichirei Corporation } \\
\text { WS } \\
\text { P Beverley }\end{array}$ & $\begin{array}{l}0 \\
3+ \\
0 \\
0 \\
0 \\
3+ \\
0 \\
3+ \\
0 \\
0 \\
2+ \\
3+ \\
1+ \\
3+\end{array}$ & $\begin{array}{l}0 \\
1+ \\
2+ \\
0 \\
0 \\
2+ \\
0 \\
1+ \\
0 \\
0 \\
0 \\
2+ \\
(+) \\
3+\end{array}$ & $\begin{array}{l}3+ \\
3+ \\
\text { Not assessed } \\
0 \\
0 \\
1+ \\
0 \\
0 \\
0 \\
0 \\
0 \\
0 \\
0 \\
0\end{array}$ & ב气 \\
\hline $\begin{array}{l}\text { Myelomonocytic antige } \\
\text { CD11a } \\
\text { CD11b } \\
\text { CD11c } \\
\text { CD13 } \\
\text { CD14 } \\
\text { CD15 } \\
\text { CD31 } \\
\text { CDw32 } \\
\text { CD33 } \\
\text { CD34 } \\
\text { CD35 } \\
\text { CD36 } \\
\text { Macrophages } \\
\text { Macrophages } \\
\text { Follicular dendritic }\end{array}$ & $\begin{array}{l}\text { ns } \\
\text { CC5-07 } \\
\text { OKM1 } \\
\text { F90.93 } \\
\text { MY7 } \\
\text { UCHM1 } \\
\text { 3C4 } \\
\text { SG134 } \\
\text { 2E1 } \\
\text { L4F3 } \\
\text { MY10 } \\
\text { To5 } \\
\text { SF1 } \\
\text { Ber-MAC3 } \\
\text { EMB11 }\end{array}$ & $\begin{array}{l}\text { WS } \\
\text { Ortho Diagnostics } \\
\text { Own laboratory } \\
\text { Coulter } \\
\text { P Beverley } \\
\text { H Stein } \\
\text { WS } \\
\text { WS } \\
\text { WS } \\
\text { WS } \\
\text { D Mason } \\
\text { WS } \\
\text { H Stein } \\
\text { Dakopatts }\end{array}$ & $\begin{array}{l}3+ \\
2+ \\
3+ \\
2+ \\
3+ \\
0 \\
1+ \\
3+ \\
2+ \\
2+ \\
0 \\
1+ \\
3+ \\
3+\end{array}$ & $\begin{array}{l}3+ \\
2+ \\
3+ \\
1+ \\
2+ \\
0 \\
3+ \\
3+ \\
0 \\
1+ \\
1+ \\
0 \\
3+ \\
3+\end{array}$ & $\begin{array}{l}0 /+ \\
0 /+ \\
0 /+ \\
2+ \\
0 /+ \\
0 \\
0 \\
1+ \\
0 \\
0 /+ \\
0 \\
0 \\
0 \\
0 /+\end{array}$ & \\
\hline $\begin{array}{l}\text { cells } \\
\text { Follicular dendritic } \\
\text { cells }\end{array}$ & $\begin{array}{l}\mathrm{R} 4 / 23 \\
\mathrm{Ki}-\mathrm{M} 4\end{array}$ & D Mason & 0 & $\mathbf{0}$ & 0 & \\
\hline \multirow[t]{2}{*}{$\begin{array}{l}\text { Miscellaneous antigens } \\
\text { CD25 } \\
\text { CD30 } \\
\text { CD45 } \\
\text { Regulatory T cells } \\
\text { P110 } \\
\text { CD16 } \\
\text { HLA-DR } \\
\text { Transferrin receptor } \\
\text { S-100 protein } \\
\text { Epithelial membrane } \\
\text { antigen } \\
\end{array}$} & $\begin{array}{l}\text { Tu69 } \\
\text { Ki-1, Ber-H2 } \\
\text { 2D1 } \\
\text { Anti-Leu-8 } \\
\text { Anti-Leu-7 } \\
\text { Anti-Leu-11b } \\
\text { F100.28 } \\
\text { OKT9 } \\
\text { Anti-S-100 }\end{array}$ & $\begin{array}{l}\text { A Ziegler } \\
\text { H Stein } \\
\text { P Beverley } \\
\text { Becton Dickinson } \\
\text { Becton Dickinson } \\
\text { Becton Dickinson } \\
\text { Own laboratory } \\
\text { Ortho Diagnostics } \\
\text { Dakopatts }\end{array}$ & $\begin{array}{l}0 /(+) \\
0 \\
3+ \\
3+ \\
0 \\
0 \\
3+ \\
1+ \\
3+\end{array}$ & $\begin{array}{l}0 /+ \\
0 \\
3+ \\
1+ \\
0 \\
0 \\
3+ \\
3+ \\
0\end{array}$ & $\begin{array}{l}0 \\
0 \\
2+ \\
0 \\
0 \\
0 \\
2+ \\
0+ \\
2+\end{array}$ & \\
\hline & E29 & D Mason & $2+$ & $1+$ & Not assessed & \\
\hline
\end{tabular}

*Antibody obtained from the Third International Workshop on Human Leucocyte Differentiation Antigens, Oxford, September 1986. Degree of staining: $0=$ no staining; $0 /+=$ a fraction (minority) of cells stain; $(+)=$ borderline staining; $1+=$ weak staining; $2+=$ moderate staining intensity; $3+=$ strong staining. IIn collaboration with Dr T Plesner, the Leukaemia Typing Laboratory, Copenhagen. 


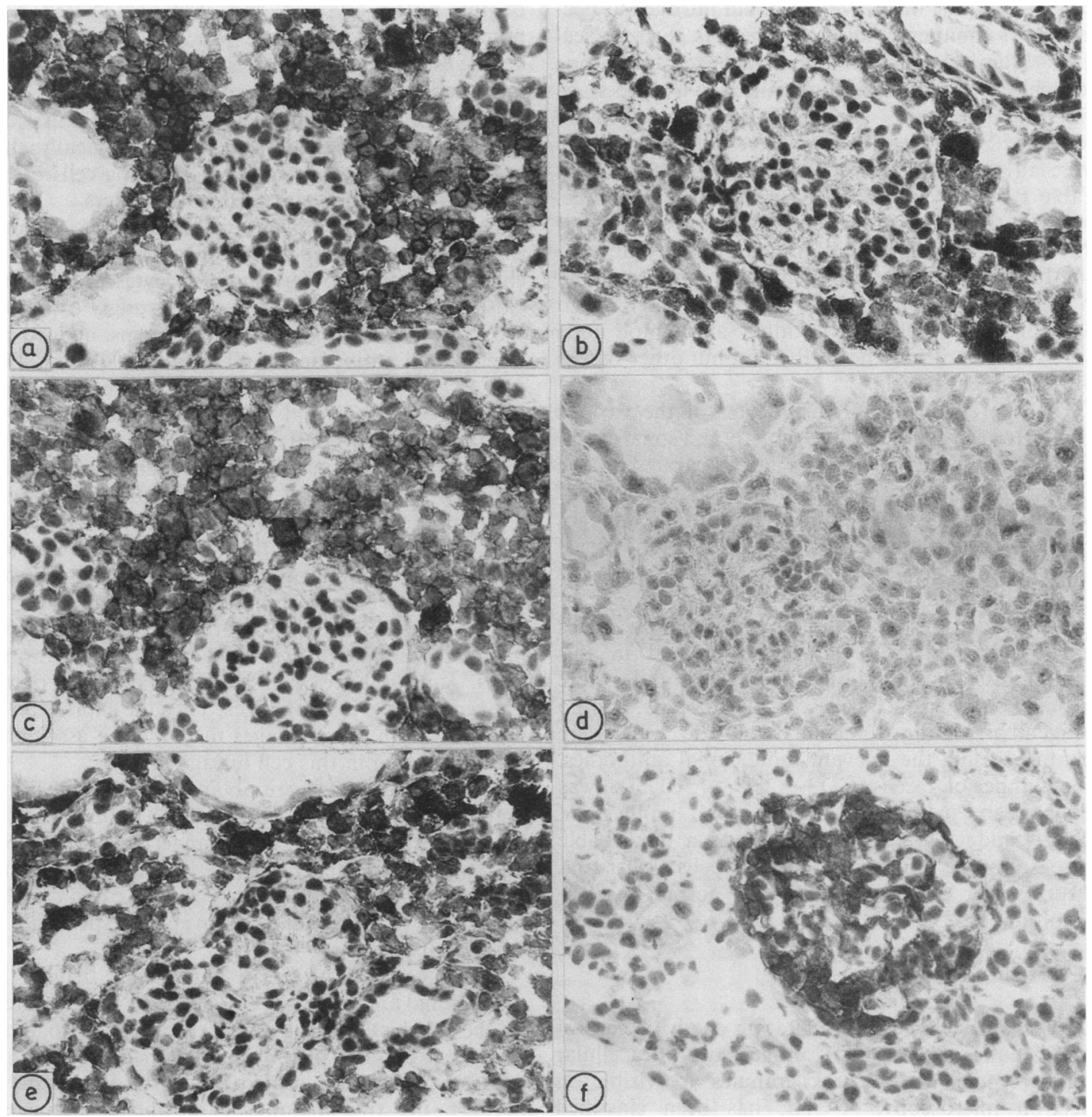

Figure Frozen section of kidney. Glomerulus surrounded by an infiltrate of HL histiocytes and some lymphocytes is shown. (a) Stained for CD6 antigen with Mab Tu33; (b) stained for CD38 antigen with Mab OKT10; (c) stained for CDIa antigen with monoclonal antibody NA1/34; (d) with monoclonal antibody OKT6; (e) stained with polyclonal antibody to S-100 protein; $(f)$ stained for CD35 antigen (C3b-receptor) with monoclonal antibody To5. Strong labelling of $H L$ histiocytes is seen in $a, b, c$, and $e$, and negative reactions in $d$ and $f$. In $f$ strong labelling is obtained on the glomerular podocytes. (a-f: immunoperoxidase.)

extended from the meninges into the deep cortex. It was less pronounced in the lungs and thymus. Erythrophagocytosis was a conspicuous feature of the histiocytes, which seemed to be cytologically benign. In the liver a pronounced and diffuse fatty change was seen. The spleen was congested with severe depletion of the lymphoid zones.

The lymph node structure was severely effaced. Apart from the histiocytic infiltration expanding the sinuses, there was complete absence of follicles and a general lymphocyte depletion of the residual $\mathrm{T}$ zones. The thymus was reduced in size, mainly due to depletion of cortical thymocytes (the so called "stress thymus"). There was, however, no evidence of congenital thymic dysplasia.

\section{IMMUNOPHENOTY PICAL STUDIES}

As most leucocyte differentiation antigens have been shown to be fairly resistant to disintegration after death $^{9}$ fresh tissue from lymph nodes, spleen, liver, 
lung and kidney was frozen in liquid nitrogen at necropsy for immunohistological analysis. Frozen sections $(7 \mu \mathrm{m})$ were cut in a cryostat, fixed in acetone and chloroform, and finally stained by a three stage immunoperoxidase technique, as previously described. ${ }^{10}$ The antibodies selected for this study were all monoclonal except the anti-S-100 protein. Table 1 briefly describes their reactivity and source. Many of the monoclonal antibodies were obtained at the Third International Workshop and Conference on Human Leucocyte Differentiation Antigens, held in Oxford in September 1986, details of which are to be published. ${ }^{11}$ Sections of kidney and lymph node were stained with all the antibodies, but other tissues with a selected panel.

The expression by HL histiocytes of the various leucocyte antigens is given in table 1 , and some examples of the staining reactions are illustrated in the figure. For comparison, the immunophenotypes of dermal Langerhans' cells and conventional phagocytic histiocytes (studied in sections from cystic breast disease) were also examined, and the results are included in table 1 .

The nature of the lymphocytes in lymph nodes and tissue infiltrates was also examined in this immunohistological analysis. The lymph nodes were virtually depleted of B cells and plasma cells, and no antigen presenting follicular dendritic cells were identified using the relevant monoclonal antibodies. The number of $\mathrm{T}$ cells $(\mathrm{CD} 2+, \mathrm{CD} 3+, \mathrm{CD} 5+)$ was reduced and comprised about equal numbers of CD4 + and CD8 + cells. There was a remarkable increase in the number of Leu-7 + cells (killer and natural killer cells) compared with normal reactive lymph nodes.

\section{Discussion}

Langerhans' cells or interdigitating dendritic cells of lymph nodes express CD1 antigen and intracellular S-100 protein, and Birbeck granules are visible on electron microscopy. ${ }^{12} 13$ HL has been classified previously as one of the non-Langerhans' cell histiocytoses as it lacks any of the above cellular markers. ${ }^{14}$ In the present study it has been shown that the proliferating cells in HL may express a unique phenotype sharing characteristics of both the Langerhans' cell and the phagocytic macrophage lineage.

In HL the clinical presentation is non-specific and rather variable, and for this reason a diagnosis after death is quite common. ${ }^{4}$ Although a positive family history was not present in our patient, the clinical findings were consistent with those seen in HL and included hypertriglyceridaemia, hypofibrinogenaemia, and immunological disturbances. This differs from what is seen in Langerhans' cell histiocytosis, ${ }^{4512}$ so called malignant histiocytosis (now usually recognised as anaplastic large cell lymphoma
Herlin, Pallesen, Kristensen, Clausen

of the $\mathrm{Ki}-1+$ type $^{15}$ and virus associated haemophagocytic syndrome, ${ }^{16}$ which lacks central nervous system disease and is often associated with increased immunoglobulin concentrations.

The characteristic histiocytes of HL were first observed at necropsy in our patient. Histologically, they bore no resemblance to the proliferating cells of the first two of the above mentioned disorders.

Extensive immunophenotypical analysis of fresh frozen tissue obtained at necropsy was performed to characterise the proliferating histiocytes of HL more closely. It disclosed that the cells strongly expressed the conventional macrophage antigens defined by monoclonal antibodies of CD groups ${ }^{11} 4,11 \mathrm{a}, 11 \mathrm{~b}$, $11 \mathrm{c}, 13,14,31$, w32, 34, and by the monoclonal antibodies Ber-MAC3 and EBM11. The expression of CD38, CD6, HLA-DR, S-100 protein and epithelial membrane antigen may indicate a high degree of acti- $\vec{A}$ vation in HL histiocytes. CD38 and HLA-DR antigen $\vec{\omega}$ are non-lineage specific antigens that are associated with cell activation, and the CD6 antigen (expressed by normal macrophages at low density) is associated with activation in a functional subpopulation of CD4 $+\mathrm{T}$ cells. A recent report stated that epithelial membrane antigen is expressed in activated lymphocytes, ${ }^{17}$ and we have often seen poor expression of this antigen in tissue macrophages. Thus the expression ơ this antigen in macrophages may well be associate with activation in this cell lineage as well.

Interesting results were obtained with monoclona? antibodies to the CDla antigen. Both antibodies used reacted strongly with skin Langerhans' cells, but OKT6 gave repeatedly negative and NA1/34 intense positive staining of HL histiocytes (fig $1 \mathrm{c}$ and d). This finding may reflect a difference in epitope specificity of these antibodies.

The expression of CDla antigen (as defined by monoclonal antibodies $\mathrm{NAl} / 34$ ) and of $\mathrm{S}-100$ protein by the HL histiocytes was unexpected, and together with the expression of conventional macrophage antigens, this indicates that there is a "hybrid" phenotype between the two main arms of the mononuclear $\delta$ phagocyte system - namely, Langerhans' cells and $₹$ phagocytic macrophages. The former express CD1a 옹 antigen and S-100 protein in high density and little $>$ or no "conventional" macrophage antigens; the opposite is true for phagocytic macrophages.

The immunohistological localisation of S-100 $\alpha$ and $\beta$ subunits in the bone marrow derived mononuclear $\tilde{O}$ phagocyte system has recently been outlined by Taka- N hashi et $a l^{18}$ using monospecific antibodies to these $\widetilde{O}$ subunits. They confirmed the presence of the $\beta$ sub- 0 unit in the Langerhans' cell arm of this system (Lan- $\frac{\mathbb{\Phi}}{\overparen{2}}$ gerhans' cell, indeterminate cells of the skin, $\stackrel{?}{+}$ interdigitating cells of the lymph nodes, histiocytosis- 7 $\mathrm{X}$ cells). Moreover, they found the $\alpha$ subunit to be $\stackrel{\circ}{\circ}$ widely distributed among cells of the other arm of the $\stackrel{\mathbb{Q}}{\stackrel{\oplus}{\oplus}}$ system - that is, monocytes, most tissue macrophages, $\overrightarrow{\mathbb{D}}$ 
lung alveolar macrophages, some Kupffer cells, but also epitheloid cells and Langerhans' giant cells in granulomatous reactions. Their results suggest that cells of the macrophage system under normal conditions may be subdivided according to their immunoreactivity solely with the S-100 $\alpha$ subunit or solely with the $\beta$ subunit.

The meaning of the aberrant $S-100 \beta$ subunit expression in HL histiocytes in our case, which by most other criteria were phagocytic histiocytes, is not understood, but perhaps an abnormal activation of the HL histiocytes, as suggested by Goldberg and Nezelof ${ }^{5}$ may be associated with an additional expression of the $\mathrm{S}-100 \beta$ subunit in some cases.

Few previous studies have been reported on the immunological markers of HL histiocytes. Wieczorek et al $^{19}$ examined frozen tissue from one case with a limited panel of antibodies and reported the cells to be negative for S-100 protein, OKT6 (CDla), OKM1 (CD11b), OKM5 and Leu-3a (CD4), but positive for HLA-DR, Leu-M3, and Leu-M1. Goldberg and Nezelof ${ }^{5}$ studied frozen tissue sections from two cases, and HL histiocytes were positive for OKM1 (CD11b) and HLA-DR, but their results with several other monoclonal antibodies were not considered to be conclusive, probably for technical reasons. ${ }^{5}$

Necropsy showed a total aplasia of B zones and a pronounced depletion of $\mathrm{T}$ lymphocytes in lymph nodes and diffuse infiltrates of histiocytes. Although defects of the immune system have been suspected in HL, few immunological studies have been done. ${ }^{6720}$ The distribution of peripheral blood $\mathrm{T}$ and $\mathrm{B}$ lymphocytes investigated during a quiescent phase of the disease was found to be normal. This agrees with the findings of Ladisch et $a l^{6}$ who, in contrast to our study, found defective lymphocyte mitogenesis. B cell function, as judged by immunoglobulin concentrations, has usually been intact, although some exceptions have been reported. ${ }^{46}$ Investigation of in vitro immunoglobulin synthesis in our patient clearly showed a complete functional B cell defect, together with enhanced suppressor $T$ cell activity.

A partial defect in natural killer cell activity with no additional effect of in vitro interferon is a characteristic finding in HL. ${ }^{420}$ Repeated plasma exchanges have led to improvement in natural killer cell activity, monocyte mediated antibody dependent cytotoxicity, and lymphocyte mitogenic responses. This indicates that the cellular defects are acquired rather than intrinsic. ${ }^{720}$ It is still unclear, however, why the cellular defects shown are not also reversible in vitro. We believe that the cellular immune defect is an important component of the HL syndrome, presumably contributing to the uncontrolled proliferation of the cell lineage specific for $\mathrm{HL}$.

This study was supported by the Danish Cancer Society. We are grateful to the research workers listed in the table for generously providing monoclonal antibodies.

\section{References}

1 Farquhar JW, Claireaux AE. Familial haemophagocytic reticulosis. Arch Dis Child 1952;27:519-26.

2 MacMahon HE, Bedizel M, Ellis CA. Familial erythrophagocytic lymphohistiocytosis. Peadiatrics 1963;32:868-79.

3 Perry MC, Harrison EG, Burgert EO, Gilchrist GS. Familial erythro-phagocytic lymphohistiocytosis. Report of two cases and clinico-pathologic review. Cancer 1976;38:209-18.

4 Janka GE. Familial erythrophagocytic lymphohistiocytosis. Eur J Pediatr 1983;140:221-30.

5 Goldberg J, Nezelof C. Lymphohistiocytosis. A multifactorial syndrome of macrophagic activation. Clinicopathological study of 38 cases. Haematol Oncol 1986;4:275-90.

6 Ladisch S, Holiman B, Poplack DG, Blaese RM, Immunodeficiency in familial erythrophagocytic lymphohistiocytosis. Lancet 1978; ;:581-3.

7 Ladisch S, Ho W, Matheson D, Pilkington R, Hartman G. Immunological and clinical effects of repeated blood exchange in familial erythrophagocytic lymphohistiocytosis. Blood 1982;60:814-21.

8 Tauris P. Plaque-forming cells in man. I. Basic technical results obtained with the protein A technique. Scand J Immunol 1983;18:241-8.

9 Pallesen G, Knudsen LM. Leucocyte antigens in human post mortem tissues: their preservation and loss as demonstrated by monoclonal antibody immunohistological staining. Histopathology 1985;9:791-804.

10 Pallesen G, Beverley PCL, Lane EB, Madsen M, Mason DY, Stein H. Nature of non-B, non-T lymphomas: an immunohistological study on frozen tissues using monoclonal antibodies. J Clin Pathol 1984;37:911-18.

11 McMichael AJ, Beverley PCL, Cobbold S, et al. Leucocyte typing III. In: White cell differentiation antigens. Oxford: Oxford University Press, 1987 (in press).

12 Nezelof C, Barbey S. Histiocytosis nosology and pathobiology. Pediatr Pathol 1985;2:441-80.

13 Beckstead J, Wood G, Turner R. Histiocytosis X cells and Langerhans' cell: enzyme histochemical and immunological similarities. Hum Pathol 1984;15:826-33.

14 Chu T, D'Angio GJ, Favara BE, Ladisch S, Nesbit M, Pritchard J. Histiocytosis syndromes in children. Lancet 1987;i:208-9.

15 Stein H, Mason DY, Gerdes J, et al. The expression of the Hodgkin's disease associated antigen $\mathrm{Ki}-1$ in reactive and neoplastic lymphoid tissue. Evidence that Reed-Sternberg cells and histiocytic malignances are derived from activated lymphoid cells. Blood 1985;66:848-58.

16 Risdall RJ, McKenna RW, Nesbit ME, et al. Virus-associated hemophagocytic syndrome. A benign histiocytic proliferation distinct from malignant histiocytosis. Cancer 1979;44: 993-1002.

17 Delsol G, Gatter KC, Stein H, et al. Human lymphoid cell express epithelial membrane antigen. Implications for diagnosis of human neoplasms. Lancet 1984;ii:1124-9.

18 Takahashi K, Isobe T, Ohtsuki Y, Sonobe H, Takeda I, Akagi T. Immunohistochemical localization and distribution of S-100 proteins in the human lymphoreticular system. Am J Pathol 1984;116:497-503.

19 Wieczorek R, Greco MA, McCarthy K, Bonetti F, Knowles DM. Familial erythrophagocytic lymphohistiocytosis. Immunophenotypic, immunohistochemical and ultrastructural demonstration of the relation to sinus histiocytes. Hum Pathol 1986;17:55-63.

20 Perez N, Virelizier J-L, Arenzana-Seisdedos F, Fischer A, Griscelli C. Impaired natural killer activity in lymphohistiocytosis syndrome. J Pediatr 1984:104:569-73.

Requests for reprints to: Dr Troels Herlin, Department of Pediatrics, University Hospital, DK-8000 Aarhus C, Denmark. 